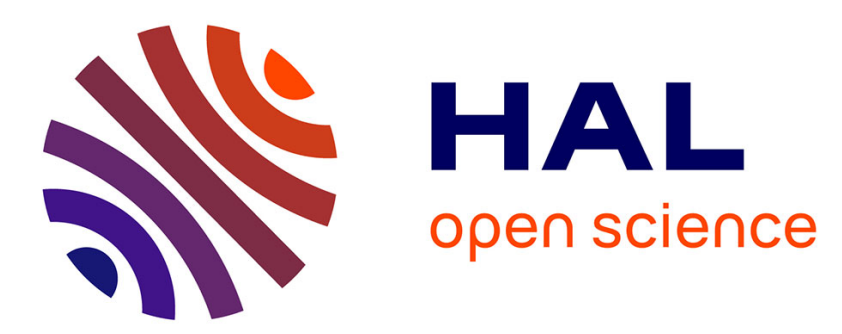

\title{
Assessment of emerging and innovative techniques considering Best Available Technique's performances
}

Valérie Laforest

\section{To cite this version:}

Valérie Laforest. Assessment of emerging and innovative techniques considering Best Available Technique's performances. Resources, Conservation and Recycling, 2014, Volume 92, pp.Pages 11-24. 10.1016/j.resconrec.2014.08.009 . emse-01062043

\section{HAL Id: emse-01062043 \\ https://hal-emse.ccsd.cnrs.fr/emse-01062043}

Submitted on 3 Nov 2014

HAL is a multi-disciplinary open access archive for the deposit and dissemination of scientific research documents, whether they are published or not. The documents may come from teaching and research institutions in France or abroad, or from public or private research centers.
L'archive ouverte pluridisciplinaire HAL, est destinée au dépôt et à la diffusion de documents scientifiques de niveau recherche, publiés ou non, émanant des établissements d'enseignement et de recherche français ou étrangers, des laboratoires publics ou privés. 


\title{
Assessment of emerging and innovative techniques considering Best Available Technique's performances
}

\author{
Valérie LAFOREST \\ V. Laforest: UMR CNRS 5600 EVS Ecole des mines de Saint-Etienne- I. Fayol 158 cours Fauriel, \\ Saint-Etienne, F42023, e-mail:laforest@emse.fr, Phone: +33 477.42.66.21
}

Abstract

For the past twenty years, the European context has been policy-driven by several directives to reduce pollution, one of the most important for industries being the industrial emissions directive (IED). The IED's objective is to minimise pollution from various industrial sources throughout the European Union. One means of attaining the objective is to implement techniques which have at least the same performance as reference techniques called best available techniques (BAT) given at European level. The study of existing methodologies on performance assessment of proven or emerging techniques has made it apparent that there are none taking into account the 12 criteria proposed by the Annex III of the IED to evaluate technique performances. Even if innovative techniques are not considered by the IED, support to (public or private) researchers in their development in terms of assessment methodology must be proposed. This is what we present in this article.

The methodology based on a tree-structured information system (objectives, criteria, indicators) and a qualitative assessment of indicators (environmental, technical, economic and social) is an initial approach to an innovative technique assessment method considering BAT on laboratory or industrial scales. In an aim to adapt the criteria and indicators to a specific process, assessment methodologies must be adaptable. Our method allows for choosing indicators to comply perfectly with the process studied. Only the first level of the tree is fixed. The other branches could be adapted to the case studied. Performance assessment is based on a five-level scale coupled with a simple multicriteria analysis (MCA) method. Three different applications (sludge valorisation, urban wastewater treatment, soil remediation) were carried out to validate the methodology, two of them are presented. Applications of this methodology show its usefulness in the validation of techniques for specific process and local application of the BAT concept and the performance assessment regarding BAT definition. It can then be used to detect innovative and emerging techniques to be proposed for the reviewing of the European BREF documents.

Keywords

Best available technique (BAT), assessment, emerging and innovative techniques, BAT criteria.

\section{Introduction}

Developing or adapting new techniques to prevent pollution generation or impacts is the huge stake of the century. Due to global, regulatory and social constraints, these actions must be accompanied by environmental, social and technical assessment. Cleaner production strategies (UNEP, 2001) and the Industrial Emission European Directive (IED) with the concept of Best Available Techniques (BAT) reflect this point of view (Laforest, 2008)(Giner-Santonja, 2012). In fact, for the past twenty years, the European context has been policy-driven by several directives to reduce pollution; we can notice that two important ones for industries being the Integrated Pollution 
Prevention and Control (IPPC) directive abrogated by the IED and the framework directive on water (WFD). The IED's objective is to minimise pollution from various industrial sources throughout the European Union. One mean of attaining the objective is to implement techniques which have at least the same performance as reference techniques called BAT given at European level. This implementation is supported by an environmental permit which must be obtained before operating. This permit is driven by several obligations for example to conform to emission limit values based on BATAEL (Best Available Techniques Associated Emission Level) and to prove the implementation of, wherever possible, a technique having an equivalent performance as BAT. More than a "static" obligation, this permit must be revised periodically to take into account changes in BAT conclusions. The assessment is based on a comparison between the plant's current performance and that which could be obtained with BAT.

The BAT concept was defined in the IPPC directive and is now integrated into the IED. The principle of BAT, as defined initially by the IPPC directive, has become a significant issue for industry: the implementation of this Directive actually compels companies to apply techniques which have the same performance as BAT. The BAT principle is defined as being "the most effective and advanced stage in the development of activities and their methods of operation which indicate the practical suitability of particular techniques for providing in principle the basis for emission limit values designed to prevent and, where that is not practicable, generally to reduce emissions and the impact on the environment as a whole" (directive, 2008).

The terms "best", "available" and "techniques" are detailed as follows:

$>$ 'techniques' includes both the technology used and the way in which the installation is designed, built, maintained, operated and decommissioned;

$>$ 'available' techniques mean those developed on a scale which allows implementation in the relevant industrial sector, under economically and technically viable conditions, taking into consideration the costs and advantages, whether or not the techniques are used or produced inside the Member State in question, as long as they are reasonably accessible to the operator, and

$>$ 'best' means most effective in achieving a high general level of protection of the environment as a whole.

This definition is reinforced by the Annex III of the IED, which exposes 12 criteria to be taken into account for the determination of BAT. Unfortunately, this information does not seem to be sufficiently clear and useful for a proper environmental performance assessment of techniques seen as BAT (De Chefdebien 2001) (Laforest 2004). This fact has been highlighted by a study aiming at assessing the degree of clarity of the consideration to be taken into account for BAT assessment in order to clarify them and thus improve their use.

With this end in view, a questionnaire was devised comprising two simple questions concerning the considerations and distributed to our sample population. Having listed the twelve considerations, we asked them: to put them in order of importance, to give definition criteria for each consideration.

The sample, composed of 40 people (industrialists, researchers, public or para-public institutions, technical centres and associations), answered the questionnaire are all deeply involved in environmental issues. The study carried out revealed a great number of redundancies and heterogeneity in the considerations contained in Annex III and then a difficulty to use them. A new definition of them is necessary for good take up and use (Laforest, 2004).

In order to support decision-makers (industrialists, authorities) in the choice, the assessment or the validation of techniques as BAT, IED requires the European Commission to organise an exchange of information concerning BAT between member states, NGO and the industries concerned (Article 13 of the IED). Nevertheless, the directive does not impose the application of a specific technique. The EIPPCB (European IPPC Bureau) has the role of coordinating, planning the information exchange and assessing and validating the results of the exchange which are summarised in the BAT Reference documents called BREF (Bailly, 2001)(Laforest, 2008). Two types of BREF exist: sectorial BREF 
considering sectors listed in the Annex 1 of the IED and horizontal BREF applicable to several sectors (EIPPCB, 2014). Moreover, it is possible to have several BREF for a sector (e.g. the chemical industry).

The techniques presented in each BREF as BAT are identified at the European level and for the industrial sector concerned as a whole (Schoenberger, 2011) (Giner-Santonja, 2012). These techniques have proved their efficiency in preventing environmental impacts, and when this is not practicable, reducing emissions and the impact on the environment as a whole (article 3 of the IED). However for a local application, reference techniques in the BREF concerned could sometimes not be the relevant BAT. Other techniques can be assessed as BAT in terms of performance for a local application. Moreover, a BAT presented in a BREF could be relevant for one installation but less efficient for another of the same sector. Thus, BREFs developed for the industrial sector cannot represent each individual facility (Schoenberger, 2011).

Besides these definitions, it is necessary to consider that an emerging or innovative technique can be validated as a BAT for a specific and local application because of the local and specific conditions on implementation. In this line of thought, emerging and innovative techniques could be validated as BAT in specific cases for a local and specific application but not for a BREF because these techniques must have proven their efficiency.

With this idea in mind, we focused our research on the support of these new techniques. The objective was to propose a methodology to support the development of innovative and emerging techniques by comparing them to BAT given by the European process. IED defines emerging technique as "a novel technique for an industrial activity that, if commercially developed, could provide either a higher general level of protection of the environment or at least the same level of protection of the environment and higher cost savings than existing best available techniques". An innovative technique is a technique which presents a novelty and not directly available on the market.

This results in the possibility of comparing the innovation to BAT from BREF. For this comparison, BREF documents are useful knowing that a list of BAT is given for each unit of the production process.

Acronyms: IED, Industrial Emission Directive; BAT, Best Available Techniques; BREF, Best available REFerence document; IPPC, Integrated Prevention Pollution and Control; WFD, Water Framework Directive; BATAEL, BAT Associated Emission Level; LCA, Life Cycle Analysis; MCDA, Multi-Criteria Decision Analysis; COD, Carbon Oxygen Demand; WWTP, WasteWater Treatment Plant; MCA, Multi-Criteria Analysis.

\section{Existing tools}

Despite the existence of the Sevilla process and the need to justify the performance of techniques to be considered as BAT, no official methodologies are proposed and used by the European Commission. Nevertheless, several methodologies have been developed to determine BAT. The objectives of these methodologies are essentially:

- To assess industry performance as BAT for Integrated Environmental Authorization (Krajnc, 2007)(Cikankowitz, 2008)(Giner-Santonja, 2012)(Schollenberger et al., 2008) (Ibáñez-Forés et al., 2013)(Laforest, 2004)(Laforest and Cikankowitz, 2006)

- To assess performance of techniques to validate them as BAT or to determine BATAEL (Dijkmans, 2000)(Schultmann, 2001)(Geldermann and Rentz, 2004)(Georgopoulou, 2008)(BREF ECM, 2006)(Derden et al., 2002)(Mavrotas et al., 2007)(Polders, 2012)(De Chefdebien, 2001)(Nicholas, 2000)(Bréchet and Michel, 2007)(Bréchet, 2009)(Zarkovic et al.,2011)

Linked to the definition of BAT, these tools are based on technical, environmental and economic criteria and can use both qualitative and quantitative parameters. Ibáñez-Forés (2013) proposed a methodology to assess "sustainable BAT" comprising economic, environmental, technical and social indicators. This methodology for decision makers provided ecoefficiency indicators based on quantitative assessment of these four criteria families. Results are given on a spider diagram which represents the sustainability footprint of each scenario. Environmental indicators are based on LCA (Life Cycle Analysis) methodology, economic, technical and social indicators are based on the 
European document on Economics and Cross-media effects (BREF ECM, 2006). Currently, the BREF ECM presents a methodology to assess environmental impacts inspired by LCA methodology (BREF ECM, 2006). However, although LCA is based on a consensual method of environmental impact assessment (ISO 14040), it is a global impact tool assessment that is time-consuming and remains siteindependent (Nicholas, 2000) in ISO standards. Nevertheless, LCA can be carried out at site level, although more specific information would be needed. Moreover, even if quantitative data is used, it can only evaluate potential impacts due to the characterisation factors determined at a country or continent scales. In addition, an LCA application needs a lot of data which are often not available for assessment especially at lab scale or for emerging or innovative techniques. Its major drawbacks are (1) it could be complex to implement (non existing data, no equilibrium in the material balances), (2) it is almost limited to environmental criteria, (3) it does not take into account local criteria and (4) it has higher cost (ISO 14044). Moreover, it is also possible to make a LCA for social and economic purposes, but those variants are not currently covered by an ISO standard. Due to the definition of BAT (local conditions, technical, social (for us considering risk criteria), economic and environmental criteria must be taken into account) (articles 15 and 18 of the IED), LCA is still not totally suitable. Then, LCA is not suitable for our application due to high complexity and associated costs.

Since early 2000 and despite the pressure from the IPPC directive, only few methodologies correspond exactly to the IPPC/IED requirements and the BAT definition. Among the referenced ones the VITO methodologies (Dijkmans, 2000)(Derden, 2002)(Polders, 2012) and a reference installation approach developed by Geldermann and Rentz (2004) can be mentioned. However, these methodologies are relevant for selecting or determining BAT for BREFs at EU level and for installation at plant level respectively or for BATELs determination. Dijkmans (2000) focuses on the fact that BAT can be selected at plant level but primarily need to be determined at sector level. So Dijkmans (2000) has developed a qualitative approach, based on expert judgment, to assist the Flemish authorities in defining BAT for specific sectors and to inform the competent authorities of developments in BAT. This methodology has been applied by Derden (2002) to identify BAT for the fruit and vegetable companies at the Belgium area. To complete these works, Polders (2012) has proposed a methodology based on quantitative data to determine BATAELs for industrial wastewater pollutants to support the permitting authorities in the Flemish region of Belgium. Then, Derden and Huybrechts (2013) have applied Dijkmans and Polders methodologies respectively to determine BAT for reducing decabromodiphenyl ether emission from textile industry via wastewater and to determine the BATAEL for the Flemish textile industry. Geldermann and Rentz (2004) differentiate BAT determination and assessment of cross-media aspects. They have proposed an integrated approach for BAT determination at EU level. Geldermann and Rentz (2004) highlights that this procedure, called reference installation, corresponds to the structure of the life cycle assessment but does not follow life cycle thinking "cradle to grave" because the scope of the IPPC-information exchange is focused on a "gate-to-gate" examination. Moreover, it does not use the analysis models which quantify the potential environmental impact from data inventory (consumption and emission or inputs and outputs) of the system studied. In the perspective to transfer technologies to industrialising countries, Schollenberger et al (2008) has proposed a methodology based on metric from economic, environmental and technical parameters. The method which aims at being country specific is using non-dimensional metrics and then allows the simultaneous consideration of parameters from the dimension aforementioned. Specific national conditions are only based on national emission limit values. This method can be used both by decision makers and local authorities for the accreditation of BAT and by technology suppliers to prove the performance of a technique.

Because of the quantity of quantitative and qualitative data needed for BAT assessment (economical, technical, environmental and social criteria), the use of a multi-criteria decision analysis (MCDA) like, for example AHP, ELECTRE or PROMETHEE (Raymond, 2008) is required. Dijkmans (2000), Schultmann (2001) and Geldermann (2004) have developed MCDA methods to assess and select techniques as BAT. The quantitative decision making tool developed by Georgopoulou et al (2008) supports end-users in environmental and economic BAT performance or a combination of BAT in the case of Greek appliances. It could be useful for the choice of a candidate to BAT when quantitative data are available.

As a BAT is defined for an industrial sector, Mavrotas et al (2007) proposed the method named COMBAT (Combinatorial Optimization with Multiple criteria for BAT selection) to determine the

*Corresponding author. Tel: +33477426621

Email address: laforest@emse.fr 
panel of BAT that satisfies as much as possible economic and environmental criteria. By the way of a multiobjective optimization, COMBAT tool helps decision-makers to fully explore the available option in a variety of ways (Goal programming, Pareto optimal solutions).

As the definition of BAT by the European commission may also depend on market equilibrium (Bréchet et Michel, 2007), Bréchet et al (2009) have worked on a methodology based on linear programming modelling of productive processes and on internalization of the external costs generated by operations. The application to the lime industry has shown that (1) in general there is not a single BAT; combination of BAT could be relevant, (2) internalization of the external costs can influence the choice of the techniques. Considering, the economic assessment, Schultman et al. (2001) have developed a methodology to determine cost involved in emission reduction measure. Zarkovic et al (2011) have studied the application of BAT for paper mill effluent treatment. They used efficiency indicators to evaluate the technical performances. Merve Kokabas et al (2009) have shown the applicability of the BREF for textiles to a textile mill by analysis of water and energy consumption. Barros et al (2009) have proceeded to the application and evaluation of BAT in the case of the seafood industry (mussel canning processing) in Galicia-Spain.

Considering the use of BATAEL for the performance assessment of techniques, Krajnc et al (2007) have developed a method based on a fuzzy logic model. This method could be used both for selection techniques and for interpretation of results for permit conditions.

Despite the existence of the 12 criteria given by the European directive on industrial emissions (Annex III), the bibliographic review shows that few researchers use them as a departure point for assessment methodology. Giner-Santonja et al. (2012) have based their MCDA support method on the analysis of the 12 considerations. They have identified 3 clusters of criteria (economic, environmental and social) in which each consideration is represented. Then, for each cluster, criteria are evaluated considering a qualitative assessment. A multi-criteria analysis (MCA) method is carried out to treat the data. Moreover, the methodology developed aims at assessing units of production process for the Integrated Environmental Authorization (Giner-Santonja, 2012). Previously to this work, De Chefdebien (2001), Laforest (2004), Laforest \& Cikankowitz (2006) and Cikankowitz (2008) had analysed these 12 considerations in order to propose BAT assessment methodology to evaluate the techniques and the production processes respectively. Table 1 presents the results of these comparative studies.

Table 1: Comparison of work conducted on the study of the 12 considerations of the IPPC directive

\begin{tabular}{|c|c|c|}
\hline Dechefdebien (2001) & Laforest (2004) & Laforest \& Cikankowitz (2006) \\
\hline $\begin{array}{l}\text { Analysis of the } 12 \text { considerations } \\
\text { Preliminary cutting : organisation } \\
\text { of the considerations given } \\
\text { characterising indicators } \\
\rightarrow 4 \text { topics (emissions, natural } \\
\text { resources, risks, costs) } \\
\text { with } 16 \text { indicators }\end{array}$ & $\begin{array}{l}\text { Analysis of the } 12 \text { considerations } \\
\text { Cutting of the considerations in } 4 \\
\text { hierarchical levels : objectives, } \\
\text { criteria, indicators and } \\
\text { parameters } \\
\rightarrow 7 \text { objectives, } 22 \text { indicators } \\
\rightarrow \text { and } 52 \text { parameters } \\
\rightarrow \text { Structuring and classification } \\
\text { of the considerations } \\
\text { considering their } \\
\text { importance/ relevance }\end{array}$ & $\begin{array}{l}>\text { Analysis of IPPC directive objectives } \\
\text { Identification of criteria, indicators } \\
\text { and parameters of evaluation } \\
\text { considering the structure adopted } \\
\text { by Laforest (2003) } \\
>\text { Application to metal finishing } \\
\text { facilities } \\
\rightarrow 4 \text { objectives, } 12 \text { criteria, } 36 \\
\text { indicators and } 89 \\
\text { parameters }\end{array}$ \\
\hline
\end{tabular}

Table 1 shows that De Chefdebien and Laforest have the same conclusions given the heterogeneity of each consideration and the restructuration needed of them.

Moreover, study of the existing methodologies has made it apparent that there are none to evaluate new (innovative or emerging) techniques in order to support researchers (public or private) in their development. The stake in this article do not concerned proven techniques but innovative or emerging technique developed at lab scale or with very few applications. These techniques could be

*Corresponding author. Tel: +334774266 21

Email address: laforest@emse.fr 
considered as BAT at local scale that is to say in specific conditions in accordance with the article 15 and 18 of the IED. They are not in line for a BAT selection at the European level for BREF elaboration. This is what we propose to present in this article. The next section will present the methodology we have developed. The fourth section will develop two applications to illustrate the use of the methodology. Then a discussion on the feedback and perspectives will finish this article.

\section{Methodological development}

The methodological development is presented in this section. It follows the research already done on the elaboration of a methodology for evaluation at production facility level (Cikankowitz, 2008)(Cikankowitz, 2013) and at process scale for the Zero Plus LIFE European Project (Zero Plus, 2009).

The steps which will be developed below are:

- Identification of the objectives of BAT (linked to the IED)

- Consideration study: arborescence (tree structure) proposition

- Indicator identification and selection

- Qualitative or quantitative assessment of indicators

- Data analysis for conclusion on the innovative technique

\subsection{Identification of BAT performance objectives}

Studies of IPPC, IED and BAT definition have made 4 principal objectives apparent. Each technique must comply with them to be considered as a BAT (Cikankowitz, 2008): Objective $\mathrm{n}^{\circ}$

- $\quad$ : to prevent and reduce environmental impact of production and treatment units

- 2: to prevent risks

- 3: to ensure industrial availability and

- $\quad$ 4: to ensure economic viability.

3.2 Consideration studies: tree structure proposition

Annex III of the IED gives the 12 criteria for determining best available techniques (Table 2). As we have already mentioned, these criteria are not used very much for the elaboration of performance assessment methodology of techniques considering BAT.

Table 2: 12 criteria for determining BAT (Appendix III of IED)

\begin{tabular}{ll}
\hline $\begin{array}{l}\text { N\# } \\
\text { Consideration }\end{array}$ & Description of the consideration \\
\hline C1 & the use of low-waste technology \\
C2 & the use of less hazardous substances \\
C3 & the furthering of recovery and recycling of substances generated and used in the process and of waste, where \\
& appropriate \\
C4 & comparable processes, facilities or methods of operation which have been tried with success on an industrial scale \\
C5 & technological advances and changes in scientific knowledge and understanding \\
C6 & the nature, effects and volume of the emissions concerned \\
C7 & the commissioning dates for new or existing installations \\
C8 & the duration of time needed to introduce the best available technique \\
C9 & the consumption and nature of raw materials (including water) used in the process and energy efficiency \\
C10 & the need to prevent or reduce to a minimum the overall impact of the emissions on the environment and the risks to it \\
C11 & the need to prevent accidents and to minimise the consequences for the environment \\
C12 & information published by public international organisations \\
\hline
\end{tabular}

Studies of the 12 criteria (Laforest, 2004)(De Chefdebien, 2001)(Giner-Santonja, 2012)(Laforest, 2008)(Perrin, 2010) have shown that each one of them is dependent on a different decision information level. Moreover, no economic criteria are taken into account. In addition, some of them can be objectives, others criteria, indicators or parameters. The 12 criteria must therefore be organised by associating them in a hierarchical manner. Then the analysis should be tree-structured (Figure 1) allowing for indicator assessment. This tree is based on the "criterion-indicator-parameter" trilogy to 
answer an objective. Maystre (1999) has defined these elements as:

Criterion: subject among which the assessment will be done to attain the objective

D Indicator: calculated value from parameters, given information of an environmental phenomenon or geographical zone.

Parameter: quantitative or qualitative measure or observation

The methodology is therefore based on the principle of MCA. The different levels are achieved by sliding considering each objective presented above and the 12 criteria. Each 'IED criterion' is dispatched logically in criterion, indicator and parameter.

Figure 1 Hierarchical organization of the information system

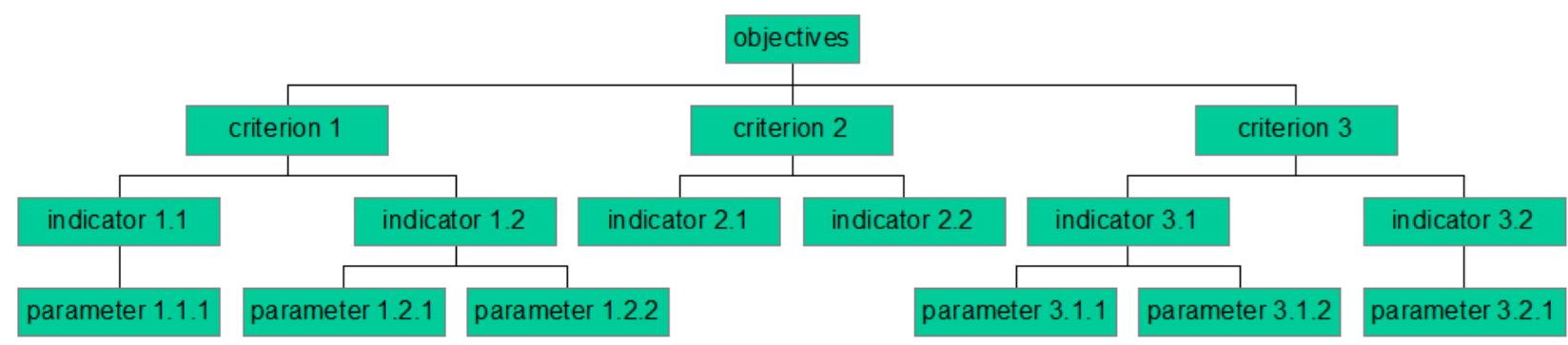

In order to fill the gap on economic criteria, four considerations were added. First, the European Zero Plus project results were used (ZeroPlus, 2009). The deliverable DL 5002 of this European project considers 2 economic criteria (investment return rate and operative costs). Moreover, the work of Ibáñez-Forés et al. (2013) proposed 4 economic criteria following the guidelines in the reference document on Economics and Cross-Media Effects (investment cost, payback period, total annual cost and net annual savings). Having these references in mind and by the fact that a qualitative assessment will be done because of the prospective analysis objective and a lack of quantitative data, we have chosen criteria which could be qualitatively assessed. Thus, 4 considerations were added and numbered from $\mathrm{C} 13$ to $\mathrm{C} 16$ as followed.

- C13. Investment payback period

- C14. Cost reduction (raw materials, waste treatment, etc.)

- C15. Cost reduction of maintenance

- C16. Cost reduction of non-conformity.

\subsection{Selection of indicators}

Considering the application studied (innovative and emerging techniques), some indicators could not be relevant for the assessment. Therefore, these indicators will not be used. As examples, the criteria C7 (commissioning dates for new or existing installations) and C12 (information published by public international organisations) could not be relevant because innovative or emerging techniques have not yet been implemented and no information has been widely published at European level in pursuance of $\mathrm{C} 12$ to date. Nevertheless the criteria $\mathrm{C} 12$ is used to compare the case-study to existing BAT by the way of a bibliographic review.

Indicator selection is done with experts and a bibliographic review notably the BREF in reference.

\subsection{Indicator assessment}

To compare techniques which run differently and which are not determined as BAT, it is not always possible to use a method based on running parameters (quantitative assessment). As a general basis, the assessment will therefore be based on a qualitative evaluation. Nevertheless, quantitative data will be used, when available, for some of the indicators to compare some criteria. We therefore use a scoring system with 5 levels as presented in the Table 3. 


\begin{tabular}{cl}
\hline Score & \\
\hline$\ll+2 »$ & Very good result comparing to the reference process \\
$\ll+\mathbf{+ 1} »$ & Good result comparing to the reference process \\
$\ll \mathbf{0} »$ & Equal result comparing to the reference process \\
$\ll-\mathbf{1} »$ & lower result comparing to the reference process \\
$\ll-\mathbf{2} »$ & A significant lower result comparing to the reference process \\
\hline
\end{tabular}

As the number of indicators evaluated could be very important, "Because a person cannot keep the meanings of more than seven (plus or minus two) alternatives in mind simultaneously, larger numbers encourage coding habits to form and allow preferences to develop" (Krippendorff, 2004), we propose using a MCA for the treatment and analysis of the results. Studies on MCA methods done by Raymond (2009) prompted us to use the simplest method: the weighting sum. The sum is done for each positive mark (equation 1). Then, this result is divided by the number of marks obtained considering positive, negative and neutral marks. So, if the result is higher than $50 \%$, the technique could be supposed to be a best technique as the reference one for the situation studied.

$$
\begin{array}{r}
T=\frac{\sum_{i=1}^{N} w_{i} V_{i}}{N} \times 100 T=\frac{\sum_{i=1}^{N} w_{i} V c_{i}^{i}}{N} \times 100 \\
\text { Equation 1 }
\end{array}
$$

$V_{i}$ is the value of the criteria number $i: V_{i}=1$ if the comparison to the reference technique is "++" or "+" and if not $V_{i}=0$

$N$ is the total number of criteria

$w_{i}$ is the weight of the criteria

\section{Applications}

The application of the methodology and more particularly its indicators is specific to the process studied. It is necessary to adapt indicators to each case as follows:

(1) to select relevant criteria for the case studied

(2) to identify indicators for the specific assessment of the technique

(3) to compare and evaluate the performance of the technique quantitatively and qualitatively

Three applications were performed to validate the methodology. Each of them relates to the development of the validation of new techniques at laboratory or industrial scale. The applications are:

- Hydroxide sludge valorisation, at laboratory scale

- Urban wastewater treatment, at industrial scale

- Soil remediation at laboratory scale: This application corresponds to the use of cyclodextrine to eliminate the Polycyclic Aromatic Hydrocarbon pollution in a soil by insitu bioremediation.

In order not to overload the article, the two first are presented in this article: at laboratory scale (Hydroxide sludge valorisation) and at industrial scale (urban wastewater treatment).

\subsection{Hydroxide sludge valorisation as pollutant trapper}

Metal finishing is one of the sectors which contribute the most to industrial pollution. Due to its unique production, metal finishing consumes water and discharges wastewater containing metallic ions, cyanide, COD, etc. Therefore, this activity is bound to the IED. For about $65 \%$ of all workshops, initiatives and actions designed to limit environmental impacts are typically end-of-pipe techniques. Wastewater composed mainly of heavy metals is mostly treated by co-precipitation of metal ions in 
hydroxide. Some species such as chromates may require an oxidation/reduction treatment. In fact, hexavalent chromium compounds need to be reduced to trivalent (chromium (III) ions) before the precipitation as chromium (III) hydroxide. This reduction is made at $\mathrm{pH}$ values under 2.5 . The most common reducing agent is sodium bisulphite. After filtration, the hydroxide sludge obtained is disposed of in various sectors. This technique is described in the BAT REFerence documents (BREF), under "Best Available Techniques for metal finishing treatment and plastic finishing treatment" (BREF STM, 2006). It is important to take into account that France produces $180 \mathrm{kt} / \mathrm{a}$ (kt per year) of metal sludge compared to the overall European production which averages $950 \mathrm{kt} / \mathrm{a}$ (Perrin, 2009). Considering the BREF STM, several sludge valorisation processes exist such as hydro and pyrometallurgy, for aluminium recuperation but these techniques operate by separating the streams of each component (BREF STM, 2006). Therefore, the new innovative process aims at valorising this whole sludge as pollutant sorbent in order to retain the polluting species contained in the industrial aqueous effluents. The chosen pollutant for this preliminary study is Chromium (+VI) (Perrin, 2009).

This new process consists in suspending polymetallic hydroxide sludge in a reactor containing industrial wastewater contaminated by chromate ions (CrVI). This mixture is stirred without $\mathrm{pH}$ adjustment. The outputs can be treated directly in the precipitation tank in order to eliminate dissolved heavy metals from the sludge due to the acidic $\mathrm{pH}$ of the chromate solution. The first experimental results have been encouraging. Nevertheless, despite the good performance of this new process (Figure 2) at lab scale, finishing (end-of-pipe) techniques are needed to conform wastewater emission limit values. Figure 2 shows that the emission limit values proposed by the French Decree of the $30^{\text {th }}$ of June 2006 considered IPPC-compatible can be attained. Then, ion exchange resins could be used to eliminate residual CrVI as well as other metals (ZnII, NiII, etc.) in the effluent before discharge (Perrin, 2009). This configuration could be as presented in Figure 3.

Figure 2 Comparison of results obtained after adsorption to emission limit values given by the French decree the $30^{\text {th }}$ June 2006

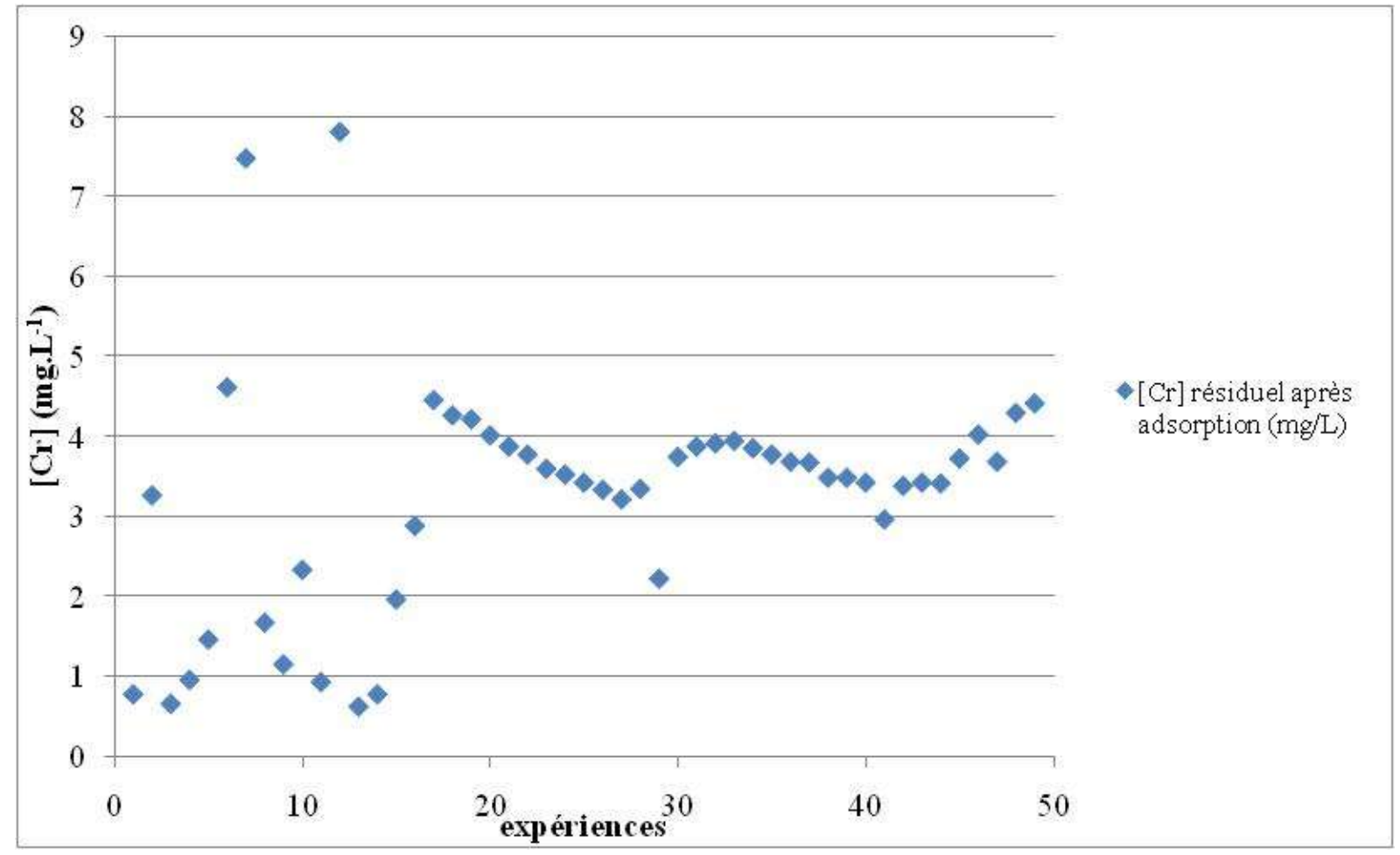




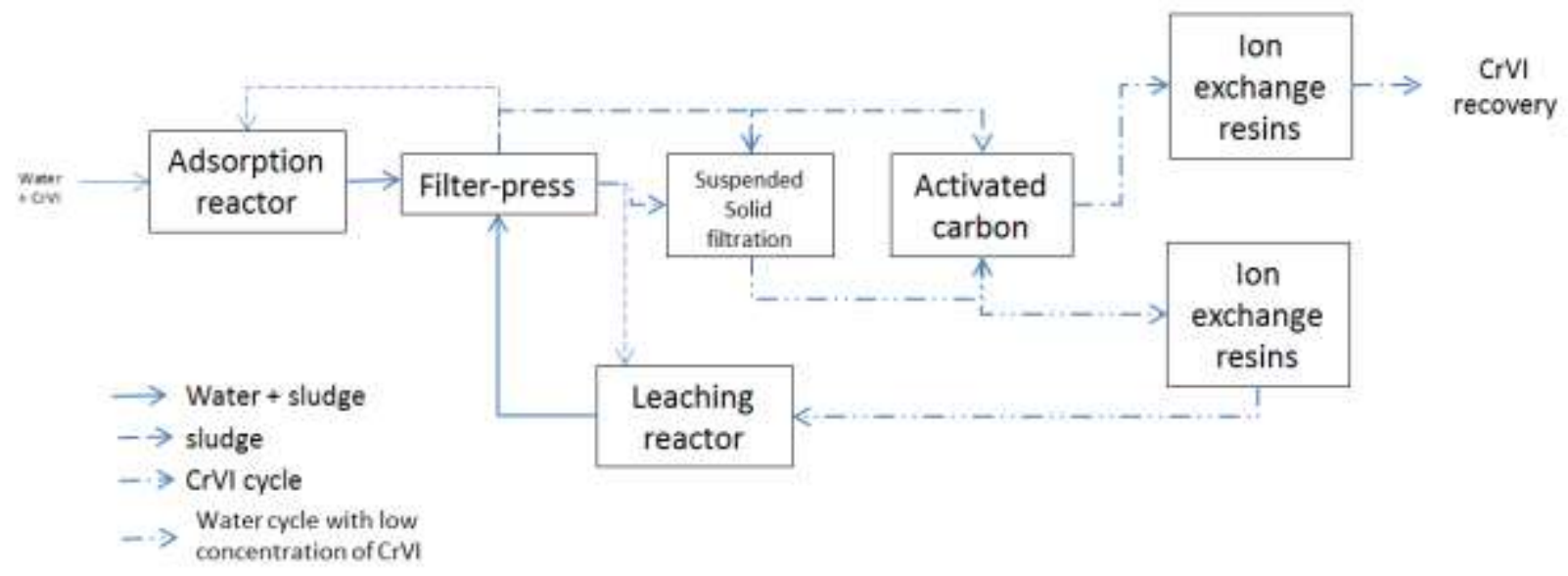

The evaluation concerns the characteristics of this new technique to the classical chromate treatment process with sodium bisulphite considered as the BAT referenced in the BREF STM.

The qualitative assessment is done between the sludge valorisation process as pollutant trapper compared and the reduction step of chromate in an industrial wastewater treatment plant (WWTP) considered as BAT in the STM BREF. The structuration of the assessment is done related to the 4 objectives presented before.

Objective 1: to prevent and reduce environmental impact of production and treatment units

As presented in the Figure 3, the sludge valorisation process is able to valorise the CrVI as a secondary raw material and to use sludge produced by the wastewater treatment plant as pollutant trapper. The classical chromate reduction process is not able to do so. Thanks to the ion exchange resin, the output water can be looped as rinsing water or for leachate operation. Then, the process proposed can reduce both the emission in the water and the fresh water consumption. Moreover, this process reduces the sludge amount produced by the WWTP compared to the classical reduction of chromate implemented in the WWTP. Nevertheless, the adsorbent process can increase the hazardous and toxic substances in the sludge because of the adsorption step. At the end of the use of the sludge as trapper, sludge will have a more dangerous potential than the BAT process. But leachate of the sludge/CrVI matrix will recover the CrVI and the sludge could be valorised as new materials for ceramists or cemeteries. One of the advantages of this new process is to avoid the use of sodium bisulphite.

Considering the design of the new process, energy consumption can be different. In fact, if only one tank is used then less devices is needed. Then the energy consumption could be a little bit higher than the BAT process but the cost will not be very significant.

Objective 2: to prevent risks

Our technique can avoid completely the use of sodium bisulphite which implies a reduction of the hazard of the products used and associated risks. Chromic acid could be recovered thanks to the lixiviation step.

Objective 3: to ensure industrial availability

The production of sludge is less important with the new technique than the BAT reference process. Nevertheless it is less easy to implement. The new technique is easy to run and do not need additional and specific training. However, the solid phase could complicate the maintenance than a 
liquid phase process.

Perrin (2009) has shown that, even if the new technique is reliable, it is extremely dependant of the suspended sludge quantity and its size grading.

This new technique is adaptable to the evolution of the regulations. The modification of the sludge masse can improve its performance (Perrin, 2009).

Objective 4: to ensure economic viability.

The most expensive parts (considering investments) of the new technique are resins, analyser for dissolved metals and crushers for sludge. Moreover, this technique runs with sludge and water produced by the WWTP. Comparing to the BAT, it reduce the cost of inputs (CrVI, sulfuric acid, sodium bisulphite). Nevertheless, the reuse of sludge could increase the maintenance costs because sealing by the sludge ca be observed. Because of the interest of the results, partners have considered the economic viability of the process.

The BAT process seems to be cheaper for investment because of the simpler installation. Nevertheless, it needs chemicals to reduce the chromate and it is not possible the save inputs.

Considering these arguments, Table 4 presents the results of the assessment. Sub-objectives and criteria have been identified first of all by the sliding game: each 'IED criterion' is dispatched logically in criterion, indicator and parameter. Moreover, STM BREF, Cikankowitz (2008) and discussion with our industrial partnership help us to establish the table of assessment. Thus, marks concern the comparison with the chromate treatment with sodium bisulphite considering as BAT in the BREF STM.

Table 4 Comparison of the innovative process of sludge valorisation to the chromate treatment with sodium bisulphite considered as BAT

\begin{tabular}{|c|c|c|c|c|}
\hline Objectives & Sub-objectives & Criteria & IED considerations & Mark \\
\hline \multirow{8}{*}{$\begin{array}{l}\text { to prevent and limit } \\
\text { environmental impact of } \\
\text { production and treatment } \\
\text { units }\end{array}$} & \multirow{4}{*}{$\begin{array}{l}\text { Consumption control }+ \\
\text { valorisation }\end{array}$} & \multirow[t]{2}{*}{ Water } & C3 & +2 \\
\hline & & & C9 & +1 \\
\hline & & Energy & C9 & -1 \\
\hline & & $\begin{array}{l}\text { Reduction of chemicals } \\
\text { loss by drag-out }\end{array}$ & C9 & NA \\
\hline & \multirow[t]{2}{*}{ Discharge treatment } & Liquid effluents & C6 & +2 \\
\hline & & Solid wastes & C1 & +1 \\
\hline & \multirow{2}{*}{\multicolumn{2}{|c|}{$\begin{array}{l}\text { Discharge treatment (internal and external } \\
\text { valorisation) }\end{array}$}} & C3 & +1 \\
\hline & & & C6 & +1 \\
\hline \multirow[t]{4}{*}{ to prevent risks } & \multirow{2}{*}{\multicolumn{2}{|c|}{ Chemicals, hazardous substances }} & $\mathbf{C 2}$ & +2 \\
\hline & & & $\mathbf{C 3}$ & +2 \\
\hline & \multicolumn{2}{|c|}{$\begin{array}{l}\text { The need to prevent or reduce to a minimum the } \\
\text { overall impact of the emissions on the } \\
\text { environment and the risks to it }\end{array}$} & C10 & +1 \\
\hline & \multicolumn{2}{|c|}{$\begin{array}{l}\text { The need to prevent accidents and to minimise the } \\
\text { consequences for the environment }\end{array}$} & C11 & +1 \\
\hline \multirow{7}{*}{$\begin{array}{l}\text { to assure an industrial } \\
\text { feasibility }\end{array}$} & \multicolumn{2}{|c|}{ Maintain and improve productivity } & & +2 \\
\hline & \multicolumn{2}{|l|}{ Ease of implementation } & C8 & -1 \\
\hline & \multicolumn{2}{|l|}{ Easy functioning } & & $\mathbf{0}$ \\
\hline & \multicolumn{2}{|l|}{ Ease of maintenance } & & -1 \\
\hline & \multicolumn{2}{|l|}{ Viability } & C4 & -1 \\
\hline & \multicolumn{2}{|l|}{ Regulation anticipation } & & +1 \\
\hline & \multicolumn{2}{|l|}{ Industrial knowledge } & C5 & +2 \\
\hline \multirow{5}{*}{$\begin{array}{l}\text { to assure an economic } \\
\text { viability }\end{array}$} & \multirow{5}{*}{ economic viability } & $\begin{array}{l}\text { Investment payback } \\
\text { period }\end{array}$ & $\mathbf{C 1 3}$ & +1 \\
\hline & & Input saving & C14 & +2 \\
\hline & & Treatment cost reduction & C14 & +1 \\
\hline & & Maintenance & $\mathbf{C 1 5}$ & -2 \\
\hline & & Non-conformity & C16 & +2 \\
\hline
\end{tabular}

The assessment was done considering 2 experts of wastewater treatment and the partner company. The result presented in table 5 shows that the new technique evaluation is composed of 8 "++", 9"+", 1"0", 4" - “, 1 " - - "and 1 "NA" (not applicable). For reason of simplicity, we have firstly considered an equal weighting of each parameter. Then, $73.9 \%$ of the criteria are in favour of the new 
technique compared to the classical chromate treatment technique. Even though validation of these results is needed, it does represent an initial assessment approach and aid in the development of this new technique, and choice of BAT at local level. This validation must be done at larger scales (pilot and industrial scales) before the implementation in the workshop in order to check the validity of these results to consider the technique as BAT. Moreover, more representative qualitative data could then be used for the assessment.

\subsection{Urban wastewater treatment}

Several wastewater treatment processes are available and proven throughout the world. However, to recycle the water treated for watering green spaces or irrigating golf courses, these techniques often require both finishing treatment to eliminate pathogenic germs and large storage units to meet the needs of the areas to be irrigated. Contrary to these existing techniques, operational tanks implemented in the Moroccan town of Benslimane, are adapted to store and polish water. These techniques have been massively implemented in Israel (more than 200 tanks) and exceptionally in Morocco since 1995. (El Haité, 2010) Wastewater treatment plant of Benslimane in its actual conception has been built in 1997 (Kerfati, 2009).

Operational tanks are big reservoirs deeply buried and filled with partially depurated wastewater which is held for several weeks (Juanico and Shelef, 1991) (Mara et al. 1996). These reservoirs have shown high performance polishing and sanitation results (microbiological, viral and parasitic parameters). They are also used for sludge treatment and digestion. This threefold function demonstrates an attractive solution for countries like Morocco where water resources are limited and technical support to manage sophisticated techniques are less developed. (El Haité, 2010)

These tanks belong to the category of extensive or "natural" treatment methods. The area required by these systems is substantial (the volume could be over than $50 \mathrm{Mm}^{3}$ ). Some tanks have reached volumes of $12 \mathrm{Mm}^{3}$. Their depth varies from 7-(10-15) $\mathrm{m}$. Due to their large size, they behave like chemical reactors and also like limnological units (lakes, dams).

The objective is to assess this urban wastewater treatment plant (WWTP) called the operational tanks of Benslimane considering BAT performances. The position of these operational tanks in the urban wastewater treatment of Benslimane is presented in the Figure 4. Comparison is made to natural and aerated lagoons (often used in tempered climate regions), biofilters (bacterial beds) and activated sludge usually used in Europe. First bibliographic review presented in the Table 5 shows that extensive treatment are adapted to the wastewater treatment for irrigating in arid area, when space is available for a reasonable price. These systems have very low running and maintenance costs, they are robust, infallibles and easy to manage (El Haité, 2010).

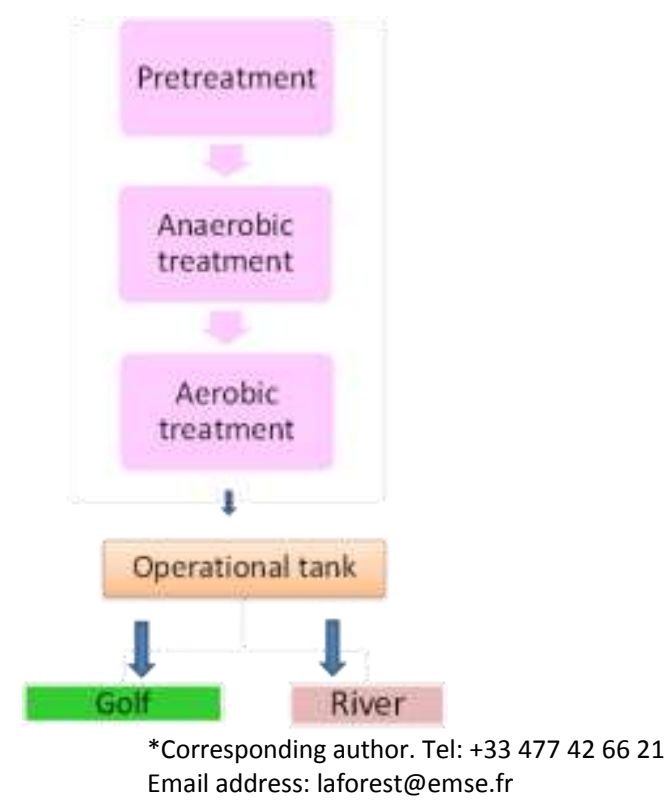


Table 5 Comparison of wastewater treatment processes

\begin{tabular}{|c|c|c|c|c|c|}
\hline & Activated sludge & Bacterial bed & Natural lagoon & Aerated lagoon & $\begin{array}{c}\text { Aerated lagoon } \\
+ \text { operational } \\
\text { tanks }\end{array}$ \\
\hline $\begin{array}{l}\text { Bacteriological quality of the } \\
\text { treated water (fecal coliform } \\
(\mathrm{FC}) \text { ) }\end{array}$ & 104 to $105 \mathrm{FC} / \mathrm{dL}$ & $\begin{array}{l}10^{4} \text { to } 10^{5} \\
\mathrm{FC} / \mathrm{dL}\end{array}$ & $10^{2}$ to $10^{3} \mathrm{FC} / \mathrm{dL}$ & $10^{2}$ to $10^{3} \mathrm{FC} / \mathrm{dL}$ & 0 to $10^{2} \mathrm{FC} / \mathrm{dL}$ \\
\hline $\begin{array}{l}\text { Chemical and biological } \\
\text { contamination reduction of the } \\
\text { water }\end{array}$ & 90 to $99 \%$ & 90 to $99 \%$ & 90 to $95 \%$ & 90 to $99 \%$ & 90 to $99 \%$ \\
\hline Storage ability & 0 & 0 & 0 & 0 & Yes \\
\hline Sludge production & $\begin{array}{l}\text { Stabilized sludge } \\
\text { only for prolonged } \\
\text { aeration }\end{array}$ & $\begin{array}{l}\text { Non stabilised } \\
\text { sludge }\end{array}$ & Stabilised sludge & Stabilised sludge & Stabilised sludge \\
\hline Sludge treatment & $\begin{array}{l}\text { Necessary to } \\
\text { sanitize the sludge }\end{array}$ & $\begin{array}{l}\text { Necessary to } \\
\text { sanitize the } \\
\text { sludge }\end{array}$ & $\begin{array}{l}\text { Unnecessary, sludge } \\
\text { is dried in drying- } \\
\text { beds. }\end{array}$ & $\begin{array}{l}\text { Unnecessary, sludge } \\
\text { ix dried in drying- } \\
\text { beds. }\end{array}$ & $\begin{array}{l}\text { Unnecessary, } \\
\text { sludge is injected } \\
\text { at the bottom of } \\
\text { the tank to be } \\
\text { mineralized. }\end{array}$ \\
\hline Surface area per inhabitant & 0,5 to $1 \mathrm{~m}^{2}$ & 0,5 to $1 \mathrm{~m}^{2}$ & 8 to $10 \mathrm{~m}^{2}$ & 1,5 to $2 \mathrm{~m}^{2}$ & 2,8 to $3 \mathrm{~m}^{2}$ \\
\hline $\begin{array}{l}\text { Investment per equiv. } \\
\text { inhabitant }\end{array}$ & 100 à 120 EUR & 100 to 150 EUR & 30 to 40 EUR & 50 to 60 EUR & 60 to 70 EUR \\
\hline Energy consumption & High & Average & $\mathrm{Nil}$ & Low & Low \\
\hline Technicality & High & High & low & Low & Low \\
\hline Operational simplicity & Complex & Complex & Simple & Simple & Simple \\
\hline Reliability in case of overload & Low & Low & Good & Good & Very good \\
\hline Robustness & Average & Good & Very good & Very good & Very good \\
\hline $\begin{array}{l}\text { Adequacy for the water } \\
\text { recyclability }\end{array}$ & Nil & Nil & $\begin{array}{l}\text { Good with a } \\
\text { maturation lagoon }\end{array}$ & $\begin{array}{l}\text { Good with a } \\
\text { maturation lagoon }\end{array}$ & Very good \\
\hline
\end{tabular}

Based on a bibliographic review and on the expertise of our partnership (EauGlobe), the methodology was adapted as follows:

- Analysis of the 12 considerations with the specificity of this application concludes that they are not all pertinent and some aspects should not be taken into account. Moreover, criteria number $\mathrm{C} 12$ is considered for the collection of information for the reservoir and for the other processes.

- Name of some indicators to analyse each process individually has been adapted.

- Results are given as a number fraction (expressed in percent, \%) of positive marks.

The matrix used for the assessment is presented in Tables 6 and 7. It rounds up considerations, objectives and sub-objectives, criteria and indicators for the analysis. Table 6 concerns more particularly environmental and technical criteria groups. Table 7 presents economic viability and risk prevention criteria groups.

Table 6 Assessment grid for environmental and technical feasibility criteria groups

\begin{tabular}{|c|c|c|c|c|}
\hline \multirow{2}{*}{$\begin{array}{c}\text { BAT } \\
\text { objectives }\end{array}$} & \multirow{2}{*}{\multicolumn{2}{|c|}{ Sub-objectives - criteria }} & Link with IPPC considerations & \multirow[t]{2}{*}{ Indicators } \\
\hline & & & Link between sub-objectives and indicators & \\
\hline \multirow{6}{*}{$\begin{array}{l}\text { to prevent and } \\
\text { limit } \\
\text { environmental } \\
\text { impact of } \\
\text { production } \\
\text { and treatment } \\
\text { units }\end{array}$} & \multirow{3}{*}{$\begin{array}{l}\text { Control of } \\
\text { consumption } \\
\text { and } \\
\text { valorisation }\end{array}$} & Water & $\begin{array}{l}\text { C3 : the furthering of recovery and recycling of substances } \\
\text { generated and used in the process } \\
\text { and of waste, where appropriate }\end{array}$ & Reuse and recycling of water \\
\hline & & Energy & $\begin{array}{l}\mathrm{C} 9 \text { : the consumption and nature of raw materials (including } \\
\text { water) used in the process and } \\
\text { energy efficiency }\end{array}$ & Energy consumption \\
\hline & & Chemicals & $\begin{array}{l}\text { C9: the consumption and nature of raw materials (including } \\
\text { water) used in the process and } \\
\text { energy efficiency }\end{array}$ & Chemical consumption \\
\hline & \multirow{2}{*}{$\begin{array}{l}\text { Discharge } \\
\text { treatment }\end{array}$} & Solid wastes & $\mathrm{C} 1$ : the use of low-waste technology & Quantity of sludge to discharge \\
\hline & & & C6 : the nature, effects and volume of the emissions concerned & Sludge stabilisation \\
\hline & \multicolumn{2}{|c|}{$\begin{array}{l}\text { Discharge treatment (internal } \\
\text { or external valorisation) }\end{array}$} & $\begin{array}{l}\text { C3 : the furthering of recovery and recycling of substances } \\
\text { generated and used in the process } \\
\text { and of waste, where appropriate }\end{array}$ & Sludge valorisation \\
\hline
\end{tabular}




\begin{tabular}{|c|c|c|c|}
\hline \multirow{9}{*}{$\begin{array}{l}\text { to assure } \\
\text { industrial } \\
\text { feasibility }\end{array}$} & $\begin{array}{l}\text { Discharge monitoring } \\
\text { To maintain and improve the } \\
\text { productivity }\end{array}$ & C6 : the nature, effects and volume of the emissions concerned & $\begin{array}{l}\text { Discharge monitoring as foreseen by } \\
\text { the regulation } \\
\text { Improvement of both facility } \\
\text { performance and water quality }\end{array}$ \\
\hline & Ease of implementation & $\begin{array}{l}\mathrm{C} 8 \text { : the duration of time needed to introduce the best available } \\
\text { technique }\end{array}$ & Ease of implementation \\
\hline & Simplicity of functioning & $\begin{array}{l}\mathrm{C} 8 \text { : the length of time needed to introduce the best available } \\
\text { technique }\end{array}$ & Simplicity of functioning \\
\hline & Simplicity of maintenance & $\begin{array}{l}\mathrm{C} 8 \text { : the length of time needed to introduce the best available } \\
\text { technique }\end{array}$ & Simplicity of maintenance \\
\hline & Reliability & $\begin{array}{l}\mathrm{C} 4 \text { : comparable processes, facilities or methods of operation } \\
\text { which have been tried with } \\
\text { success on an industrial scale }\end{array}$ & Reliability \\
\hline & $\begin{array}{l}\text { Anticipation face to evolution } \\
\text { of regulatory constraints }\end{array}$ & $\begin{array}{l}\mathrm{C} 4 \text { : comparable processes, facilities or methods of operation } \\
\text { which have been tried with } \\
\text { success on an industrial scale }\end{array}$ & $\begin{array}{l}\text { Considering the evolution of the } \\
\text { regulation. }\end{array}$ \\
\hline & & & $\begin{array}{l}\text { Robustness (acceptability of } \\
\text { overloading) }\end{array}$ \\
\hline & Technical & C7: the commissioning dates for new or existing installations & Proven industrial application \\
\hline & $\begin{array}{l}\text { evolution of scientific } \\
\text { knowledge }\end{array}$ & $\begin{array}{l}\text { C5 : technological advances and changes in scientific knowledge } \\
\text { and understanding }\end{array}$ & Scientific input \\
\hline
\end{tabular}

Table 7 Assessment grid for economic viability and risk prevention criteria groups

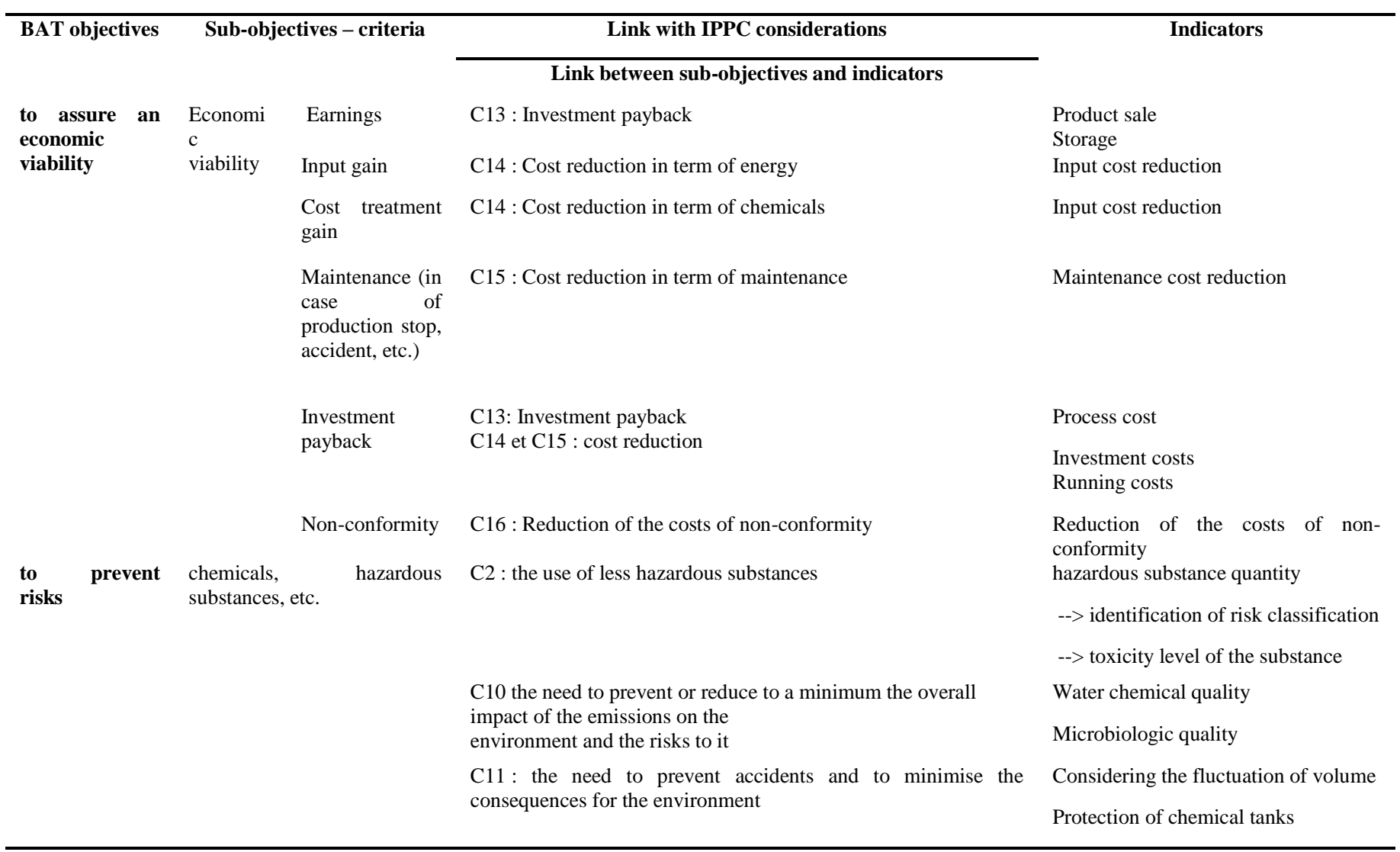

Considering these assessment grids, the depuration process was compared to 4 other processes considered as BAT in literature. Comparison of the processes presented in Tables 8, 9, 10 and 11, shows significant differences for each one. 
Table 8 Assessment of the environmental impact of urban wastewater treatment

(Scoring scale: -2 highly negative, -1 negative, 0 neutral, +1 positive, +2 highly positive)

\begin{tabular}{|c|c|c|c|c|c|c|c|c|c|}
\hline $\begin{array}{c}\text { BAT } \\
\text { objectives }\end{array}$ & \multicolumn{2}{|c|}{ Sub-objectives - criteria } & Indicators & $\begin{array}{c}\text { Activated } \\
\text { sludge }+ \\
\text { tertiary } \\
\text { treatment }\end{array}$ & $\begin{array}{c}\text { Bacterial bed } \\
\text { + tertiary } \\
\text { treatment }\end{array}$ & \multirow{2}{*}{$\begin{array}{l}\text { Natural lagoon }+ \\
\text { maturation pond } \\
\\
1\end{array}$} & \multirow{2}{*}{\begin{tabular}{|c|}
$\begin{array}{c}\text { Aerated lagoon } \\
+ \text { maturation } \\
\text { pond }\end{array}$ \\
\\
\end{tabular}} & \multirow[t]{2}{*}{$\begin{array}{c}\text { Aerated } \\
\text { lagoon }+ \\
\text { operational } \\
\text { tanks }\end{array}$} & \multirow[b]{2}{*}{$\begin{array}{l}\text { Water Input }=\text { water } \\
\text { output for each type of } \\
\text { STEP. For operationa } \\
\text { tank output quantity can } \\
\text { be higher because of the } \\
\text { storage capacity }\end{array}$} \\
\hline \multirow{7}{*}{$\begin{array}{l}\text { to prevent } \\
\text { and limit } \\
\text { environmenta } \\
1 \text { impact of } \\
\text { production } \\
\text { and treatment } \\
\text { units }\end{array}$} & \multirow[t]{3}{*}{$\begin{array}{l}\text { Control of } \\
\text { consumption } \\
\text { and } \\
\text { valorisation }\end{array}$} & Water & $\begin{array}{l}\text { Reuse and } \\
\text { recycling of } \\
\text { water }\end{array}$ & 1 & 1 & & & & \\
\hline & & Energy & $\begin{array}{l}\text { Energy } \\
\text { consumptio } \\
\mathrm{n}\end{array}$ & -2 & -1 & 0 & -1 & 0 & $\begin{array}{l}\text { No power consumption } \\
\text { for operational tanks. }\end{array}$ \\
\hline & & $\begin{array}{l}\text { Chemical } \\
\mathrm{s}\end{array}$ & $\begin{array}{l}\text { Chemical } \\
\text { consumptio } \\
\mathrm{n}\end{array}$ & -2 & -1 & 2 & 2 & 2 & $\begin{array}{lr}\text { No } & \text { chemical } \\
\text { consumption } & \text { for } \\
\text { extensive and semi- } \\
\text { extensive systems. }\end{array}$ \\
\hline & $\begin{array}{l}\text { Discharge } \\
\text { treatment }\end{array}$ & $\begin{array}{l}\text { Solid } \\
\text { wastes }\end{array}$ & $\begin{array}{l}\text { Quantity of } \\
\text { sludge to } \\
\text { discharge }\end{array}$ & -2 & -2 & -1 & -1 & 2 & $\begin{array}{l}\text { More important quantity } \\
\text { generated by intensive } \\
\text { systems. The tank allows } \\
\text { the reuse of the sludge. }\end{array}$ \\
\hline & & & $\begin{array}{l}\text { Sludge } \\
\text { stabilisation }\end{array}$ & -2 & -2 & 1 & 1 & 2 & $\begin{array}{l}\text { More stabilized sludge } \\
\text { from extensive systems } \\
\text { than intensive systems. } \\
\text { Sludge injected in the } \\
\text { tank is mineralized. }\end{array}$ \\
\hline & $\begin{array}{l}\text { Discharge } \\
\text { (internal or } \\
\text { valorisation) }\end{array}$ & $\begin{array}{r}\text { treatment } \\
\text { external }\end{array}$ & \begin{tabular}{|l} 
Sludge \\
valorisation
\end{tabular} & -2 & -2 & 1 & 1 & 2 & $\begin{array}{l}\text { Sludge in the tank is } \\
\text { easily available for the } \\
\text { reuse. Nevertheless } \\
\text { sludge can be treated as } \\
\text { the ones from the other } \\
\text { process. }\end{array}$ \\
\hline & $\begin{array}{l}\text { Discharge } \\
\text { monitoring }\end{array}$ & & $\begin{array}{l}\text { Discharge } \\
\text { monitoring } \\
\text { as foreseen } \\
\text { by the } \\
\text { regulation }\end{array}$ & 0 & 0 & 0 & 0 & 1 & $\begin{array}{l}\text { Considering the constant } \\
\text { quality of the water the } \\
\text { residence time and the } \\
\text { highest performances, } \\
\text { the monitoring planning } \\
\text { can be spaced. }\end{array}$ \\
\hline
\end{tabular}


Table 9 Assessment of the industrial feasibility of urban wastewater treatment

(Scoring scale: -2 highly negative, -1 negative, 0 neutral, +1 positive, +2 highly positive)

\begin{tabular}{|c|c|c|c|c|c|c|c|c|}
\hline $\begin{array}{c}\text { BAT } \\
\text { objectives }\end{array}$ & $\begin{array}{l}\text { Sub-objectives } \\
\text { - criteria }\end{array}$ & Indicators & $\begin{array}{c}\text { Activated } \\
\text { sludge }+ \\
\text { tertiary } \\
\text { treatment }\end{array}$ & $\begin{array}{l}\text { Bacterial bed } \\
+ \text { tertiary } \\
\text { treatment }\end{array}$ & $\begin{array}{c}\text { Natural } \\
\text { lagoon }+ \\
\text { maturation } \\
\text { pond }\end{array}$ & $\begin{array}{c}\text { Aerated } \\
\text { lagoon }+ \\
\text { maturation } \\
\text { pond }\end{array}$ & $\begin{array}{c}\text { Aerated } \\
\text { lagoon }+ \\
\text { operational } \\
\text { tanks }\end{array}$ & Observation \\
\hline \multirow{9}{*}{$\begin{array}{l}\text { to assure an } \\
\text { industrial } \\
\text { feasibility }\end{array}$} & $\begin{array}{l}\text { To maintain } \\
\text { and improve } \\
\text { the } \\
\text { productivity }\end{array}$ & $\begin{array}{lr}\text { Improvement } & \text { of } \\
\text { both } & \text { facility } \\
\text { performance } & \text { and } \\
\text { water quality }\end{array}$ & 1 & 1 & 1 & 1 & 2 & $\begin{array}{l}\text { Tank are easy to put in place } \\
\text { and to maintain }\end{array}$ \\
\hline & $\begin{array}{lr}\text { Ease } & \text { of } \\
\text { implementation }\end{array}$ & $\begin{array}{ll}\text { Ease } & \text { of } \\
\text { implementation } & \end{array}$ & -2 & -2 & 2 & 2 & 2 & $\begin{array}{l}\text { Tank are easy to put in place } \\
\text { and to maintain }\end{array}$ \\
\hline & $\begin{array}{l}\text { Simplicity of } \\
\text { functioning }\end{array}$ & $\begin{array}{ll}\text { Simplicity } \\
\text { functioning }\end{array}$ & -2 & -2 & 2 & 2 & 2 & $\begin{array}{l}\text { Tank are easy to put in place } \\
\text { and to maintain }\end{array}$ \\
\hline & $\begin{array}{l}\text { Simplicity of } \\
\text { maintenance }\end{array}$ & $\begin{array}{ll}\begin{array}{l}\text { Simplicity } \\
\text { maintenance }\end{array} & \text { of }\end{array}$ & -2 & -2 & 2 & 2 & 2 & $\begin{array}{l}\text { Aerated system equipment } \\
\text { and lagoon do not need } \\
\text { complicated maintenance. }\end{array}$ \\
\hline & Reliability & Reliability & 1 & 1 & 2 & 2 & 2 & $\begin{array}{l}\text { Intensive systems are very } \\
\text { sensitive to contamination } \\
\text { and load variation. }\end{array}$ \\
\hline & $\begin{array}{ll}\text { Anticipation } & \\
\text { face } & \text { to } \\
\text { evolution } & \text { of } \\
\text { regulatory } & \\
\text { constraints } & \end{array}$ & $\begin{array}{ll}\text { Considering } & \text { the } \\
\text { evolution of } & \text { the } \\
\text { regulation. } & \end{array}$ & 1 & 1 & 1 & 1 & 2 & $\begin{array}{l}\text { Because of the excellent } \\
\text { quality of the water due to the } \\
\text { residence time, operational } \\
\text { tank can help to anticipate } \\
\text { regulatory constraints. }\end{array}$ \\
\hline & & $\begin{array}{l}\text { Robustness } \\
\text { (acceptability } \\
\text { overloading) }\end{array}$ & -1 & -1 & 1 & 1 & 2 & $\begin{array}{l}\text { Operational tanks are more } \\
\text { adaptable to load variation. }\end{array}$ \\
\hline & \multirow{2}{*}{$\begin{array}{lr}\text { Technical } & \\
\text { progress } & \text { and } \\
\text { evolution } & \text { of } \\
\text { scientific } & \\
\text { knowledge } & \end{array}$} & $\begin{array}{l}\text { Proven industrial } \\
\text { application }\end{array}$ & 2 & 2 & 2 & 2 & 2 & They are all proven systems \\
\hline & & Scientific input & 0 & 0 & 0 & 0 & 2 & $\begin{array}{l}\text { Because of its simplicity and } \\
\text { its efficiency, operational tank } \\
\text { constitutes a scientific } \\
\text { innovation for arid countries } \\
\text { without space constraints and } \\
\text { important water demand. }\end{array}$ \\
\hline
\end{tabular}


Table 10 Assessment of the economic viability of urban wastewater treatment

(Scoring scale: -2 highly negative, -1 negative, 0 neutral, +1 positive, +2 highly positive)

\begin{tabular}{|c|c|c|c|c|c|c|c|c|c|}
\hline $\begin{array}{c}\text { BAT } \\
\text { objectives }\end{array}$ & Sub-obj & ctives - criteria & Indicators & $\begin{array}{c}\text { Activated } \\
\text { sludge }+ \\
\text { tertiary } \\
\text { treatment }\end{array}$ & $\begin{array}{l}\text { Bacterial bed } \\
\text { + tertiary } \\
\text { treatment }\end{array}$ & $\begin{array}{c}\text { Natural } \\
\text { lagoon }+ \\
\text { maturation } \\
\text { pond }\end{array}$ & $\begin{array}{c}\text { Aerated } \\
\text { lagoon + } \\
\text { maturation } \\
\text { pond }\end{array}$ & $\begin{array}{c}\text { Aerated } \\
\text { lagoon }+ \\
\text { operational } \\
\text { tanks }\end{array}$ & Observation \\
\hline \multirow{8}{*}{$\begin{array}{l}\text { to assure } \\
\text { an } \\
\text { economic } \\
\text { viability }\end{array}$} & \multirow{8}{*}{$\begin{array}{l}\text { Economic } \\
\text { viability }\end{array}$} & Earnings & $\begin{array}{c}\text { Product sale } \\
\text { Storage }\end{array}$ & 1 & 1 & 1 & 1 & 2 & $\begin{array}{l}\text { Higher sale volume of } \\
\text { water with tank } \\
\text { solutions. }\end{array}$ \\
\hline & & Input gain & $\begin{array}{l}\text { Input cost } \\
\text { reduction }\end{array}$ & -2 & -1 & 2 & 1 & 1 & \\
\hline & & $\begin{array}{l}\text { Cost treatment } \\
\text { gain }\end{array}$ & $\begin{array}{l}\text { Input cost } \\
\text { reduction }\end{array}$ & -2 & -2 & 2 & 2 & 2 & $\begin{array}{l}\text { Except few energy } \\
\text { consumption for aerated } \\
\text { systems, there is no } \\
\text { other input }\end{array}$ \\
\hline & & $\begin{array}{l}\text { Maintenance (in } \\
\text { case of } \\
\text { production stop, } \\
\text { accident, etc.) }\end{array}$ & $\begin{array}{l}\text { Maintenance cost } \\
\text { reduction }\end{array}$ & -2 & -2 & 2 & 2 & 2 & $\begin{array}{l}\text { No complicated } \\
\text { maintenance }\end{array}$ \\
\hline & & & Process cost & -2 & -2 & 2 & 2 & 2 & $\begin{array}{l}\text { Low cost of process for } \\
\text { extensive and semi- } \\
\text { extensive systems }\end{array}$ \\
\hline & & $\begin{array}{l}\text { Investment } \\
\text { payback }\end{array}$ & Investment & -2 & -1 & 2 & 2 & 1 & $\begin{array}{l}\text { We consider that the } \\
\text { investment cost is the } \\
\text { same than activated } \\
\text { sludge. Assumption : } \\
\text { operational tanks and } \\
\text { lagoon are space } \\
\text { consuming (not true in } \\
\text { countries where space is } \\
\text { limited) }\end{array}$ \\
\hline & & & Operational costs & -2 & -1 & 2 & 1 & 1 & $\begin{array}{l}\text { Low running cost for } \\
\text { extensive and semi- } \\
\text { extensive systems. }\end{array}$ \\
\hline & & Non-conformity & $\begin{array}{l}\text { Reduction of the } \\
\text { costs of non- } \\
\text { conformity }\end{array}$ & -1 & -1 & 0 & 0 & 2 & \\
\hline
\end{tabular}


Table 11 Assessment of the risk criteria family of urban wastewater treatment

(Scoring scale: -2 highly negative, -1 negative, 0 neutral, +1 positive, +2 highly positive)

\begin{tabular}{|c|c|c|c|c|c|c|c|c|}
\hline $\begin{array}{c}\text { BAT } \\
\text { objectives }\end{array}$ & $\begin{array}{l}\text { Sub-objectives } \\
\text { - criteria }\end{array}$ & Indicators & $\begin{array}{c}\text { Activated } \\
\text { sludge }+ \\
\text { tertiary } \\
\text { treatment }\end{array}$ & $\begin{array}{c}\text { Bacterial } \\
\text { bed }+ \\
\text { tertiary } \\
\text { treatment }\end{array}$ & $\begin{array}{c}\text { Natural } \\
\text { lagoon }+ \\
\text { maturation } \\
\text { pond }\end{array}$ & $\begin{array}{c}\text { Aerated } \\
\text { lagoon }+ \\
\text { maturation } \\
\text { pond }\end{array}$ & $\begin{array}{c}\text { Aerated } \\
\text { lagoon }+ \\
\text { operational } \\
\text { tanks }\end{array}$ & Observation \\
\hline \multirow[t]{7}{*}{$\begin{array}{l}\text { to prevent } \\
\text { risks }\end{array}$} & \multirow[t]{7}{*}{$\begin{array}{l}\text { chemicals, } \\
\text { hazardous } \\
\text { substances, etc. }\end{array}$} & $\begin{array}{l}\text { Reduction of the } \\
\text { costs of non- } \\
\text { conformity }\end{array}$ & -1 & 1 & 2 & 2 & 2 & $\begin{array}{l}\text { No hazardous } \\
\text { chemicals used in } \\
\text { extensive and semi- } \\
\text { extensive systems. }\end{array}$ \\
\hline & & $\begin{array}{l}\text { hazardous } \\
\text { substance } \\
\text { quantity }\end{array}$ & 0 & 0 & 0 & 0 & 0 & \\
\hline & & $\begin{array}{l}\rightarrow \text { identification } \\
\text { of risk } \\
\text { classification }\end{array}$ & 0 & 0 & 0 & 0 & 0 & \\
\hline & & $\begin{array}{l}\rightarrow \text { toxicity level } \\
\text { of the substance }\end{array}$ & 1 & 1 & 1 & 1 & 2 & \\
\hline & & $\begin{array}{l}\text { Water chemical } \\
\text { quality }\end{array}$ & 1 & 1 & 1 & 1 & 2 & $\begin{array}{l}\text { Tanks allow } \\
\text { obtaining a good } \\
\text { quality of water in } \\
\text { keeping the fertilizer } \\
\text { value. }\end{array}$ \\
\hline & & $\begin{array}{l}\text { Microbiologic } \\
\text { quality }\end{array}$ & -2 & -2 & 1 & 1 & 2 & $\begin{array}{l}\text { Exceptional } \\
\text { performances of the } \\
\text { tanks. }\end{array}$ \\
\hline & & $\begin{array}{l}\text { Considering the } \\
\text { fluctuation of } \\
\text { volume }\end{array}$ & 0 & 0 & 0 & 0 & 0 & $\begin{array}{l}\text { High capacity of } \\
\text { tanks to manage high } \\
\text { variation of water } \\
\text { volume. }\end{array}$ \\
\hline
\end{tabular}

Table 12 gives the synthesis of the performance assessment of the operational tanks and the 4 other processes considered as BAT. Results show that operational tanks proposed $61 \%$ more advantages than activated sludge or bacterial beds and $13 \%$ more advantages than natural or aerated lagoons.

Table 12 Synthesis of the qualitative assessment of urban wastewater treatment process

\begin{tabular}{|c|c|c|c|c|c|}
\hline Mark of the criteria & $\begin{array}{c}\text { Activated } \\
\text { sludge }+ \\
\text { tertiary } \\
\text { treatment }\end{array}$ & $\begin{array}{c}\text { Bacterial bed + } \\
\text { tertiary } \\
\text { treatment }\end{array}$ & $\begin{array}{c}\text { Natural lagoon } \\
+ \text { maturation } \\
\text { pond }\end{array}$ & $\begin{array}{c}\text { Aerated lagoon } \\
+ \text { maturation } \\
\text { pond }\end{array}$ & $\begin{array}{l}\text { Aerated lagoon }+ \\
\text { operational tanks }\end{array}$ \\
\hline- & 15 & 10 & 0 & 0 & 0 \\
\hline- & 3 & 7 & 1 & 2 & 0 \\
\hline $\mathbf{0}$ & 5 & 5 & 7 & 6 & 4 \\
\hline+ & 7 & 8 & 10 & 12 & 4 \\
\hline++ & 1 & 1 & 13 & 11 & 23 \\
\hline Total & 31 & 31 & 31 & 31 & 31 \\
\hline Advantage per treatment type & $26 \%$ & $29 \%$ & $74 \%$ & $74 \%$ & $87 \%$ \\
\hline $\begin{array}{l}\text { Advantage over aerated lagoon } \\
\text { + operational tanks }\end{array}$ & $-61 \%$ & $-58 \%$ & $-13 \%$ & $-13 \%$ & \\
\hline
\end{tabular}

The Moroccan wastewater treatment plant can be considered as a BAT for the considered examples for Benslimane application in a Morocco context. However, climate conditions and input wastewater characteristics are decisive for the WWTP output water quality. This evaluation can be available for similar human and physical medium. 


\section{Discussion and Conclusion}

Environmental regulation has evolved to better protect of the environment in favour of sustainable development. Pollution prevention, emission reduction, waste production, use of raw materials and energy efficiency are the major issues of the Industrial Emissions European Directive (art 15.3 of the IED). To be authorised to run, each process concerned by the IED has to have at least equivalent performance to the reference BAT taking the local conditions into account (articles 15 and 18 of the IED). Moreover, the principles of the IED consider that each technique used or developed must take BAT performance into account. The latter is gathered in technical documents called BREFs. These documents first of all present a list of reference BAT and a list of emerging techniques that may appear in the near future as proven techniques and that may be selected as BAT. The choice of techniques by decision-makers must take into account the performances of reference BAT from BREFs and BAT conclusion when they exist. Therefore, regardless of the maturation of the process studied, performance must be ensured in order to conform to the IED consideration. As already stated, several methodologies have been developed to comply with BAT performance. However, despite the existence of the 12 criteria given by the European directive on industrial emissions (Annex 3), few assessment methodologies have taken them into account - generally a global assessment is done. Our methodology has filled this gap by considering each IED criterion proposed and structured them into an information system as a tree system. Because of the different nature of criteria in Annex III, not all of them can be used directly as proposed. In fact many of them are useful for a quantitative or qualitative assessment but others are only for identification of information. Each IED criterion was positioned in the correct place considering the 4 objectives to attain and the "criterion-indicatorparameter" trilogy. The criteria C12 (Information published by public international organisations) concerns information and data on techniques which are available to identify, evaluate and prove the existence of techniques and their efficiency. Giner-Santonja et al. (2012), De Chefdebien (2002), Laforest (2004) and Cikankowitz (2008) have identified the C12 specificity but they have not taken it into account in their assessment methodology.

Concerning the evaluation, we have chosen a qualitative structure with a 5-level score. This is often used when there is a lack of quantitative data. It could be used for direct assessment in the case of no quantitative data available or to normalize qualitative assessment in a homogeneous assessment scale. Assessment founded on multi-criteria and multi-indicators requires the use of a MCDA like, for example AHP, ELECTRE or PROMETHEE considering the objectives (Roy, 1991)(Raymond, 2008). The tree structure and normalized evaluation chosen is used for MCDA. Because we wanted to develop a simple method, representative of the system, the MCDA chosen is the weighted sum with equi-weighting for each criterion thus considering equivalent. A limitation of our approach is the way the data is managed to obtain the final result. In fact our simple proposal concerns the use of the weighted sum with an equi-weighting for each criterion. Because scores $(++)$ and $(+)$ are dealt equally and scores $(--),(-)$ and $(0)$ are dealt equally, our first approach is finally carried out with only 2 scoring levels. Nevertheless, the final result (final mark) must be accompanied by the intermediate results (comparison tables and justification of marks proposed) to be valid and to distinguish the very good or good advantages and the drawbacks of the scenario assessed.

When criteria or indicators are not equivalent, other weighting could be chosen. According to Styles (2009) and Ahlroth (2011), several weighting methods can be applied. For example, the panel weighting method which allows for the gathering of stakeholder opinion and expertise to weight criteria can be chosen (Styles, 2009) (Ahlroth, 2011). To this end, a questionnaire must be elaborated and sent to experts. Results obtained are treated in order to obtain weighting. This could be a perspective of our work.

Considering the scoring system, experts and professionals could be involved. Individual option can be scored by attributing a grade from 1 to 10 points within a given criteria. Then an average score of the criteria can be obtained by summing up the points and dividing by the number of members awarding points. Then a ranking of the scenarios could be done for decision aid (Generowicz, 2011). This scoring and ranking system could be interesting in case of the comparison of many scenarios.

With regard to the choice of a treatment process, it is really important to have a specific assessment and to adapt the criteria and indicators to the case studied. In fact, each effluent treatment process has

*Corresponding author. Tel: +33 477426621

Email address: laforest@emse.fr 
to be designed and chosen considering the specific characteristic of the effluent, the use of the effluent treated and the local implementation conditions of the process designed. Results are dependent on the application chosen: For other applications, the results could be different. When evaluating the performance of techniques considering BAT, specific considerations are taken into account (Cikankowitz, 2013) (IED, 2010). Therefore, one technique could be a BAT for one application but not for another application or another geographical localisation. El Haité (2010) has demonstrated this fact in her $\mathrm{PhD}$ thesis. In an aim to adapt the criteria and indicators to a specific process, assessment methodologies must be adaptable. Our method allows for choosing indicators to comply perfectly with the process studied. Only the first level of the tree is fixed. The other branches could be adapted to the case studied.

Moreover, regardless of the maturation of the technique, this methodology can be used to detect innovative and emerging techniques to be proposed for the improvement of the European BREF documents. Existing methodology based on quantitative assessment like LCA-based tools for example (Nicholas, 2000)(Ibáñez-Forés, 2013)(Schultmann, 2001)(Geldermann, 2001)(Georgopoulou, 2008)(Schollenberger, 2008) (Mavrotas, 2007), are not adapted to carry out an initial evaluation of new techniques (laboratory-scale development). The reason is the lack of existing data perfectly representative of the technique. The method proposed by Dijkmans (2000) is a qualitative one with a three levels scoring system. Then the assessment of our methodology is done in the same way on the base of expert judgment and to determine BAT. Nevertheless the huge difference with our methodology is the finality. Dijkmans finality is "to assist Flemish authorities in defining BAT for specific sectors and to inform the competent authorities of developments in BAT". Our objective is to help developers/researchers or company to validate an emerging or innovative technique as BAT for their own application in a specific and local context.

As shown by Cikankowitz (2013), the BAT concept can be applied to a process or an installation. A process could be one unit or a group of processes. Therefore, the application perimeter is an important issue as it could modify the results and the pertinence of the system. For example, Perrin (2009) has developed a new wastewater treatment process by hydroxide sludge valorisation. Considering the emission limit values based on BAT performance (BREF-STM and the IED compatible French regulation) the hydroxide sludge valorisation process is not efficient enough to be a BAT. When coupled to ion exchange resins, BAT performance is achievable.

Our methodology, based on a tree-structured information system and a qualitative assessment of indicators (environmental, technical, economic and social), is an initial approach to an innovative technique assessment method considering BAT at laboratory or industrial scale.

\section{Acknowledgements}

The author would like to thank Prof Jacques Bourgois for his help with this research, the three $\mathrm{PhD}$ students (C.Viglianti, L.Perrin, H.ElHaite) for their work, the Eau-Globe Moroccan Consultant as well as the surface treatment Company-SFTS for their involvement in this research project.

\section{References}

Ahlroth S, Nilsson M, Finnveden G, Hjelm O, Hochschorner E. Weighting and valuation in selected environmental systems analysis tools - suggestions for further developments, J Cleaner Production, 2011; 19:145-156

Bailly, G., Rôle des différents participants aux travaux d'élaboration des BREF, Colloque AFITE, Paris, 19 octobre 2001: available only in French

Barros MC, Magan A, Valino S, Bello PM, Casares JJ, Blanco JM. Identification of best available techniques in the seafood industry: a case study. J Cleaner Production, 2009; 17:391-399

Bréchet Th, Michel Ph. Environmental performance and equilibrium. Canadian Journal of Economics, $2007 ; 40$ (4):345-367

Bréchet T, Tulkens H. Beyond BAT: Selecting optimal combinations of available techniques, with an example from the limestone industry. Journal of Environmental Management, 2009; 90:1790-1801. 
BREF ECM. Integrated Pollution Prevention and Control Reference European document on Economics and Cross-media Effects. European Commission, July 2006;175

BREF STM. Integrated Pollution Prevention and Control Reference Document on Best Available Techniques for the Surface Treatment of Metals and Plastics. European Commission, August 2006;546

Cikankowitz A. Méthodologie d'évaluation des performances environnementales de techniques en vue de les comparer puis de les valider «meilleures techniques disponibles ». PhD thesis, 2008, 376. Environmental performance assessment methodology of techniques in order to compare and to validate them as «best available techniques » (BAT) 2008 (available only in French).

Cikankowitz A. Laforest V. Using BAT performance as an evaluation method of techniques. J Cleaner Production, 2013; 42:141-158

De Chefdebien H. BAT - BREF - IPPC ou encore MTD: les «Meilleures Techniques Disponibles». Rapport No 7-8, July-August 2001; 95-105 (available only in French).

Derden A, Huybrechts D. Brominated flame retardants in textile wastewater: reducing Deca-BDE using best available techniques. J Cleaner Production, 2013; 53:167-175

Derden A, Vercaemst P, Dijkmans R. Best available techniques (BAT) for the fruit and vegetable processing industry. Resources, Conservation and Recycling 2002; 34:261-271

Dijkmans R. Methodology for selection of best available techniques (BAT) at the sector level. J Cleaner Production, 2000; 8:11-21

Directive 2008/1/EC of the European Parliament and of the Council of 15 January 2008 concerning integrated pollution prevention and control (codified version). Official Journal of the European Union 2008. L 24/8.

eippcb, http://eippcb.jrc.ec.europa.eu/, last consultation 2014-05-22

El Haité H. Traitement des eaux usées par les réservoirs opérationnels et réutilisation pour l'irrigation. $\mathrm{PhD}$, 2010; 223 (available only in French)

European Zero Plus project (LIFE 05 ENV / E / 256). Report on legal framework on integrated pollution prevention and control. Part II: French legislative and institutional contexts: Application to the metal finishing sectors 2009

Geldermann J, Rentz O. The reference installation approach for the techno-economic assessment of emission abatement options and the determination of BAT according to the IPPC-directive. J Cleaner Production, 2004; 12:389-402

Generowicz A, Kulczycka J, Kowalski Z, Banach M. Assessment of waste management technology using BATNEEC options, technology quality method and multi-criteria analysis. J Environmental Management 2011; 92:1314-1320

Georgopoulou E. et al., BEAsT: a decision-support tool for assessing the environmental benefits and the economic attractiveness of best available techniques in industry. J Cleaner Production 2008; 16: 359-373

Giner-Santonja G, Aragones-Beltran P, Niclos-Ferragut J. The application of the analytic network process to the assessment of best available techniques. J Cleaner Production, 2012; 25:86-95

Ibáñez-Forés V, Bovea MD, Azapagic A. Assessing the sustainability of Best Available Techniques (BAT): methodology and application in the ceramic tiles industry. J Cleaner Production 2013; 51:162-176

IED. Directive 2010/75/EU of the European parliament and the council of the 24 November 2010 on industrial emissions (integrated pollution prevention and control) Official Journal of the European Union 2010. L334/17-118

ISO 14044 Environmental management - ACV 2006; 49

Juanico M, Shelef G. The performance of stabilization reservoirs as a function of design and operational parameters. Water Science and Technology, 1991; 23(6-9):1509-1516.

Krajnc D, Mele M, Glavic P. Fuzzy logic model for the performance benchmarking of sugar plants by considering best available techniques. Resources, Conservation and Recycling 2007; 52:314-330

Krippendorff K. Content Analysis - an introduction to its methodology, 2nd edition. London, Sage Publications, 2004

Kerfati A, Réutilisation en irrigation des eaux usées au Maroc, Atelier sur l'Assainissement. l'Epuration et la Réutilisation des Eaux Usées, 7-11 December, 2009, Agadir.

Laforest V, Berthéas R. Integrated environmental regulation : How to define best available techniques? 9th European Roundtable on Sustainable Consumption and Production, 12-14 May, 2004, Bilbao.

Laforest V, Cikankowitz A. Report on legal framework on integrated pollution prevention and control. DL6001_1. Life 05/ENV/E/000256 (Zero Plus project), 2006; 114

Laforest V. Applying Best Available Techniques in environmental management accounting: from the definition to an assessment method. Environmental Management Accounting for Cleaner production (5th Eman Book), 2008; 24:29-47.

Mara DD, Pearson HW, Oragui JI, Cawley LR, de Oliveira R, Silva SA. Wastewater Storage and Treatment Reservoirs in Northeast Brazil. Tropical Public Health Engineering Research Monograph No 12. University 
of Leeds, School of Civil Engineering, Leeds, England, 1996.

Mavrotas G, Georgopoulou E, Mirasgedis S, Sarafidis Y, Lalas D, Hontou V, Gakis N. An integrated approach for the selection of Best Available Techniques (BAT) for the industries in the greater Athens area using multi-objective combinatorial optimization. Energy Economics 2007; 29:953-973

Maystre, Aide à la négociation multicritère - Pratiques et conseils, Collection Gérer l'environnement, Presses Polytechniques et universitaires romandes: Aid for the multicriteria negotiation - practices and council, 1999 (available only in French).

Merve Kokabas A, Yukseler H, Dilek FB, Yetis U. Adoption of European Union's directive to a textile mill: Analysis of water and energy consumption. J Environmental Management 2009; 91:102-113

Nicholas MJ, Clift R, Azapagic A, Walker FC, Porter DE. Determination of 'best available techniques' for integrated pollution prevention and control : a life cycle approach. Trans IChemE, 2000; 78, Part B: 193-203

Perrin L, Laforest V, Bourgois J. Valorisation of Polymetallic Hydroxide Sludge as Pollutant Trappers. Recent Patents on Chemical Engineering 2009; 2(1):43-50

Perrin, L, et al. Validation du procédé Val-Boue comme meilleure technique disponible. Colloque Eau, Déchets et Développement Durable, 28-31 March, 2010, Alexandria, Egypt. (Available only in French).

Polders C, Van den Abeele L, Derden A, Huybrechts D. Methodology for determining emission levels associated with the best available techniques for industrial waste water. J Cleaner Production 2012; 29-30:113-121

Raymond G, Piatyszek E, Laforest V. Reducing the environmental impact in the metal finishing industry by employing cleaner and safer production strategies. Second International Conference on Environmental Economics and Investment Assessment. Cadiz. 28-30, May, 2008

Raymond G. Reduction des impacts environnementaux des ateliers de traitement de surface - Application de stratégies de production plus propres et plus sûres, $\mathrm{PhD}$ thesis, 2009;313. Reducing the environmental impact in the metal finishing industry - Application of cleaner and safer production strategies 2009 (available only in French)

Roy B. The outranking approach and the foundations of ELECTRE methods, Theory and Decision. 1991;31:49_ 73

Schollenberger H, Treitz M, Geldermann J. Adapting the European approach of Best Available Techniques: case studies from Chile and China. J Cleaner Production 2008; 16:1856-1864

Schoenberger H, Lignite coke moving bed adsorber for cement plants - BAT or beyond BAT? J Cleaner Production 2011; 19:1057-1065

Schultmann F, Jochum R, Rentz O. A methodological approach for the economic assessment of best available techniques. LCA Methodology 2001; 6(1):19-27.

Styles D, O’Brien P, O’Boyle S, Cunningham P, Donlon B, B. Jones M. Measuring the environmental performance of IPPC industry: I. Devising a quantitative science-based and policy-weighted Environmental Emissions Index. Environmental Science and Policy 2009; 12:226-242

UNEP, United Nations Environment Programme. Cleaner production. 2001, Available online, www.unep.fr/pc/cp/understanding_cp/home.htm, last consultation 2014-05-22

Zarkovic DB., Todorovic ZN, Rajakovic LV. Simple and cost-effective measures for the improvement of paper mill effluent treatment - A case study. J Cleaner Production, 2011; 19:764-774

ZeroPlus, Confidential report on evaluation of feasibility of industrial implementation, Deliverable DL5002, V0.7. European Life Project 05/ENV/E/000256 June 2009;170 